\section{Jurnal Mitra Pendidikan (JMP Online)}

URL : http://e-jurnalmitrapendidikan.com
JMP Online

Vol. 4, No. 10, 660-673

(C) 2020 Kresna BIP. e-ISSN 2550-0481 p-ISSN 2614-7254

\title{
UPAYA MENINGKATKAN HASIL BELAJAR PERSAMAAN \\ DASAR AKUNTANSI MELALUI METODE KOOPERATIF TIPE THINK PAIR SHARE (TPS) DI KELAS XI IPS
}

\author{
Magdalena Johanis \\ SMAN I Lobalain Kabupaten Rote Ndao
}

INFORMASI ARTIKEL

Dikirim : 16 Oktober 2020

Revisi pertama : 21 Oktober 2020

Diterima : 27 Oktober 2020

Tersedia online : 03 November 2020

Kata Kunci: Hasil Belajar, Akuntansi, TPS

Email:magdalena80@gmail.com
ABSTRAK

Penelitian ini menerapkan model Think pair share untuk meningkatkan hasil belajar siswa kelas XI IPS. Untuk mengetahui hasil belajar siswa dalam pemahaman tentang persamaan dasar akuntansi dengan menerapkan model pembelajaran think pair share.

Hasil penelitian menunjukkan bahwa aktivitas siswa pada siklus I jumlah siswa yang aktif ada 20 orang atau sebesar 55,55\% dan siklus I jumlah siswa yang aktif sebanyak 36 orang dengan prosentase $100 \%$, sedangkan ketuntasan belajar siswa pada siklus I 55,55\% dan pada siklus I meningkat menjadi $100 \%$.

Berdasarkan hasil penelitian yang dilakukan maka disimpulkan bahwa dengan menerapkan model pembelajaran Think Pair Share pada materi persamaan dasar akuntansi, hasil yang dicapai meningkat dengan mencapai 100\% diatas KKM 78. 


\section{PENDAHULUAN \\ Latar Belakang}

Pendidikan merupakan pengaruh, bantuan, atau tuntunan yang diberikan oleh orang yang bertanggung jawab kepada anak didik (Andrianto, Dedy. 2011). Pengajaran mempunyai proporsi yang paling besar, terutama di dalam pendidikan formal. Bila pengajaran diartikan sebagai perbuatan mengajar, maka tentunya adaguru yang mengajar dan siswa yang diajar atau yang belajar (Ahmad, Susanto. (2013). Kegiatan belajar mengajar merupakan satu kesatuan dari dua kegiatan yang searah. Kegiatan belajar adalah kegiatan primer, sedangkan mengajar merupakan kegiatan sekunder yang dimaksudkan untuk dapat terjadi kegiatan belajar yang optimal. Suatu kondisi pembelajaran yang kondusif dan menyenangkan diharapkan mampu membuat siswa belajar, karena secara tidak langsung siswa akan termotivasi untuk aktif dalam kegiatan belajar mengajar dikelas. Dalam kegiatan belajar mengajar terdiri atas komponen-komponen yang saling bekerjasama untuk mencapai tujuan pembelajaran. Adapun komponenkomponen tersebut antara lain: (a) peserta didik; (b) tenaga pendidik; (c) materi pelajaran; (d) media atau peralatan pembelajaran; (e) strategi dan metode pembelajaran; (f) evaluasi atau hasil penilaian; (g) lingkungan pembelajaran; serta (h) pengelolaan kelas (Agung, Iskandar. 2012). Apabila semua komponen tersebut dapat bekerjasama secara maksimal maka kegiatan belajar mengajar akan berjalan lancar dan diharapkan hasil belajar siswa baik dan tujuan pembelajaran tercapai. Kenyataanya pendidikan saat ini masih mengalami berbagai masalah, salah satu masalah yang dekat dengan hal tersebut adalah hasil belajar siswa. Hal itu ditunjukkan oleh sikap, perilaku dan prestasi belajar (nilai) siswa secara umum. Banyak siswa yang sering melalaikan tugas mereka seperti tidak mengerjakan PR atau tugas-tugas yang lain, mengacuhkan penjelasan materi dari guru, bahkan masih banyak juga siswa yang kesulitan saat mengadapi soalulangan atau ujian semester pada beberapa mata pelajaran sehingga nilai merekapun tidak maksimal. Biasanya mereka mengalami kesulitan pada mata pelajaran yang membutuhkan pemahaman, ketelitian dan perhitungan. Berdasarkan pada pemaparan tersebut dapat diambil kesimpulan bahwa hasil belajar siswa masih rendah.

Seperti halnya yang terjadi pada Siswa Sekolah Menengah Atas (SMA )Jurusan Ilmu Pengetahuan Sosial (IPS) yang beranggapan bahwa mata pelajaran ekonomi/ akuntansi khususnya materi-materi akuntansi sulit dipahami, hal tersebut diungkapan oleh beberapa siswa kelas XII IPS SMA Negeri I Lobalain. Menurut mereka untuk dapat mengerjakan soal-soal akuntansi diperlukan waktu yang lama karena mereka harus memahami, menghitung, mencatat transaksi-transaksi yang ada dengan teliti dan apabila salah dalam mencatat harus mengulang pencatatan dari awal.

Peneliti telah melaksanakan observasi awal saat Kegiatan BelajarMengajar (KBM) berlangsung di kelas XII IPS SMA Negeri I Lobalain. Keaktifan dan motivasi siswa untuk belajar akuntansi dirasa masihrendah, hal tersebut ditunjukkan dalam perilaku mereka ketika mengikuti pembelajaran akuntansi. Ada beberapa siswa yang sering membuat suasana kelas menjadi gaduh dengan lelucon yang mereka buat, akibatnya siswa yang lain menjadi ikut tertawa. Disamping itu, ada juga siswa yang tidak memperhatikan dan mengacuhkan penjelasan dari guru 
yang sedang memberikan penjelasan, bahkan siswa cenderung lebih menikmati obrolan dengan teman-teman mereka dibandingkan memperhatikan penjelasan dari guru. Hal ini menjadikan siswa tidak dapat menyerap materi pelajaran dengan maksimal, terbukti dengan adanya siswa yang masih kebingungan ketika menghadapi soal-soal akuntansi.

Berdasarkan nilai ulangan akhir semester pertama akuntansi dengan KKM (Kriteria Ketuntasan Minimum) sebesar 78 diketahui bahwa 55,55\% siswa telah lulus KKM sedangkan $\mathbf{4 4 , 4 4 \%}$ siswa tidak tuntas. Berdasarkan kondisi yang dipaparkan tersebut dapat disimpulkan bahwa hasil belajar siswa masih rendah. Peneliti juga telah melakukan wawancara beberapa siswa. Beberapa siswa mengungkapkan bahwa kondisi kelas yang tidak kondusif, teman yang suka ramai di dalam kelas, cara guru menyampaikan materi kurang jelas, menjadi alasan siswa untuk malas belajar sehingga hasil belajar mereka rendah. Salah satu alternatif yang dapat ditempuh untuk meningkatkan hasil belajar siswa adalah melalui kreativitas yang dimiliki guru dalam memilih metode mengajar. Selama ini guru sudah menggunakan metode ceramah bervariasi, tetapi masih banyak siswa yang merasa kesulitan dalam memahami konsep akuntansi sehingga perlu dicari suatu model pembelajaran akuntansi yang sesuai dengan kondisi siswa dan kelas tersebut, agar pembelajaran akuntansi dapat membuat siswa tertarik dan termotivasi. Pembelajaran Kooperatif adalah strategi pembelajaran di mana siswa belajar bersama dalam kelompok-kelompok kecil dan saling membantu satu sama lain. Dalam menyelesaikan tugasnya, setiap anggota kelompok bekerja sama dan membantu untuk memahami suatu bahan pelajaran. Terdapat beberapa tipe pembelajaran kooperatif salah satu di antaranya pembelajaran kooperatif tipe Think pair share (TPS). Pembelajaran kooperatif tipe TPS adalah jenis pembelajaran kooperatif di mana siswa belajar berpasangan, sehingga memberi siswa lebih banyak waktu untuk berpikir, merespon, dan saling membantu dalam menyelesaikan suatu permasalahan. Anita Lie (2010: 57) menyebutkan bahwa TPS adalah salah satu tipe pembelajaran kooperatif yang cocok diterapkan untuk semua mata pelajaran dan semua tingkat usia anak. Sehingga TPS juga sesuai apabila diterapkan dalam mata pelajaran ekonomi / akuntansi. Mata pelajaran ekonomi / akuntansi pada kompetensi dasar menyusun laporan keuangan perusahaan jasa adalah mata pelajaran yang membutuhkan ketelitian dan kecermatan. Alternatif penggunaan model pembelajaran kooperatif tipe TPS pada pembelajaran akuntansi diharapkan dapat meningkatkan minat, motivasi dan keaktifan siswa, dengan cara menempatkan siswa belajar secara berkelompok sehingga akan lebih mudah menemukan dan memahami konsep-konsep yang sulit apabila mereka dapat saling mendiskusikan dengan temannya. Dan pada akhirnya hasil belajar siswa pun mengalami peningkatan.

Berdasarkan latar belakang masalah yang telah diuraikan di atas, peneliti merasa perlu mengadakan suatu penelitian yang bertujuan untuk meningkatkan hasil belajar akuntansi. Dan itulah yang menjadikan peneliti tertarik mengadakan penelitian dengan mengambil judul Upaya Meningkatkan Hasil Belajar Persamaan Dasar Akuntansi Melalui Metode Kooperatif Tipe Think pair share ( TPS) Di Kelas XII IPS SMAN I Lobalain. 


\section{Rumusan Masalah}

Berdasarkan latar belakang masalah tersebut, maka peneliti merumuskan masalah yang akan diteliti yaitu bagaimana upaya meningkatkan hasil belajar persamaan dasar akuntansi melalui metode kooperatif tipe think pair share (TPS) di kelas XII IPS SMAN I Lobalain?

\section{Tujuan Penelitian}

Tujuan yang ingin dicapai dalam penelitian ini adalah untuk mendeskripsikan penerapan pembelajaran kooperatif tipe Think pair share (TPS) untuk meningkatkan hasil belajar persamaan dasar akuntansi di kelas XII IPS SMAN I Lobalain.

\section{KAJIAN PUSTAKA Pengertian Hasil Belajar}

Hasil belajar terdiri dari dua kata, yakni hasil dan belajar. Antara hasil dan belajar memiliki arti yang berbeda. Hasil ialah wujud pencapaian dan suatu tujuan yang dikerjakan, diciptakan baik secara individu maupun kelompok. Hasil tak akan pernah didapat selama seseorang tidak melakukan suatu tindakan. Sedangkan belajar adalah suatu kegiatan yang dilakukan secara sadar untuk menuju suatu perubahan. Dengan demikian dapat dipahami makna hasil belajar merupakan wujud tujuan yang diperoleh berupa kesan-kesan yang mengakibatkan perubahan pada diri individu dalam aktivitas kemandirian hidup. (A, Supratiknya. (2012). Hasil belajar adalah kemampuan yang dimiliki siswa setelah menerima pengalaman belajarnya. (Sudjana, Nana. (2011)). Hasil yang dicapai siswa melalui proses belajar mengajar yang optimal cenderung menunjukkan hasil yang berciri sebagai berikut :

a. Kepuasaan dan kebanggaan yang dapat menumbuhkan motivasi belajar intrinsif pada diri siswa. Motivasi intrinsif adalah semangat juang untuk belajar yang tumbuh dan dalam diri siswa itu sendiri, siswa tidak akan mengeluh dengan prestasi yang rendah, dan siswa akan berjuang lebih keras lagi utuk memperbaikinya, sebaliknya, hasil belajar yang baik akan mendorong siswa untuk meningkatkan apa yang telah dicapainya.

b. Menambah keyakinan akan kemampuan dirinya. Artinya siswa tahu kemampuan dirinya dan percaya siapa punya potensi yang tak kalah dari orang lain apabila siswa berusaha sebagaimana harusnya. Siswa juga yakin tidak ada sesuatu yang tidak dapat dicapai bila siswa berusaha sesuai dengan kesanggupannya.

c. Hasil belajar yang dicapainya bermakna bagi diri siswa, seperti makan tahan lama dilihatnya, membentuk perilakunya, bermanfaat untuk mempelajari aspek lain, dapat digunakan sebagai alat untuk memperoleh informasi dan pengetahuan lainnya, kemauan dan kemampuan untuk belajar sendiri serta dapat mengembangkan kreativitas.

d. Hasil belajar diperoleh siswa secara menyeluruh (komprehensif), yakni mencakup ranah kognitif, pengetahuan atau wawasan, ranah afektif atau sikap yang apresiasif, serta ranah psikomotorik, ketrampilan atau perilaku. Ranah kognitif terutama adalah hasil yang diperolehnya sedangkan ranah afektifnya 
dan psikomotorik diperolehnya sebagai efek samping yang tidak dilaksanakan dalam pembelajaran.

e. Keterampilan siswa untuk mengontrol atau menilai dan mengendalikan dirinya terutama dalam menerima hasil yang dicapainya maupun menilai dan mengendalikan proses dari usaha belajarnya. Siswa tahu dan sadar bahwa tinggi rendahnya hasil belajar yang dicapaiannya tergantung pada usaha dan motivasi belajar dirinya sendiri.

\section{Pengertian Persamaan Dasar Akuntansi}

Persamaan Dasar Akuntansi merupakan sebuah persamaan atau juga rumus dasar yang digunakan dalam setiap perhitungan akuntansi, persamaan dasar akuntansi inilah yang terus dipakai untuk dapat menyelesaikan permasalahan akuntansi lainnya baik dalam lingkup yang sederhana maupun yang lebih rumit.

Pengertian lain dari persamaan akuntansi dasar ini adalah sebuah persamaan yang berhubungan dengan harta, aset, ekualitas dan kewajiban dari pemilik suatu bisnis.

\section{Unsur-Unsur Persamaan Dasar Akuntansi}

a. Aset (Aktiva) ialah sebuah sumber daya yang sudah dikuasai oleh pihak perusahaan sebagai akobat dari sebuah peristiwa yang terjadi di masalalu dan di masa depan yang akan memanfaatkan ekonomi dari sumber haraoan yang akan diperoleh suatu perusahaan.

b. Hutang (Kewajiban) yakni sebuah tanggungjawab suatu perusahaan yang akan terjadi pada saat ini dan yang timbul dari sebuah peristiwa di masa lalu, dan suatu proses penyelesaiannya akan membutuhkan sumber daya perusahaan.

c. Ekuitas (Modal) yaitu sisa dari sebuah kepentingan yang ada di dalam aktiva yang sudah sesuai dengan perusahaat setelah di kurangi dengan kewajiban.

d. Pendapatan (Revenue) adalah salah satu aliran yang masuk atau juga peningkatan lain atas aktiva atau penurunan dari kewajiban sebuah perusahaan sebagai akibat yang terjadi dari aktivitas penyerahan, penjualan dan pembuatan sebuah barang, jasa atau aktivitas yang lainnya dan yang juga merupakan berbagai kegiatan utama yang secara terus menerus di lakukan oleh perusahaan.

e. Beban (Expenses) ialah sebuah arus keluar atau penggunaan lain dari aktiva atau penungkatan kewajiban karena ada suatu penyerahan atau pembuatan barang, jasa atau juga melakukan suatu kegiatan lain yang juga merupakan kegiatan utama yang dapat dilakukan secara terus menerus oleh perusahaan.

f. Prive (Drawing) adalah sesuatu hal dalam pengambilan aset dari perusahaan yang di lakukan oleh pemilik nya yang akan di gunakan untuk suatu kepentingan pribadinya.

\section{Rumus Persamaan Dasar Akuntansi}

1. Keseimbangan Antara Harta dan Modal

Harta merupakan sebuah kekayaan yang dimiliki oleh perusahaan dan merupakan sumber pembelanjaan untuk melakukan kegiatan usaha tersebut. Oleh karena itu, harta juga harus sama atau seimbang dengan sumber pembelanjaan. Sumber pembelanjaan yang dapat diperoleh dari pemilik disebut 
ekuitas/modal. Keseimbangan atau kesamaan biasanya dinyatakan dalam suatu persamaan yaitu persamaan akuntansi.

Hubungan kedua hal di atas juga dapat dinyatakan sebagai keseimbangan antara harta dan modal, sehingga persamaannya dapat ditulis sebagai berikut ini :

\section{HARTA $=$ MODAL}

2. Harta Sama dengan Utang Ditambah Modal

Harta sebuah sperusahaan yang digunakan sebagai sumber pembelanjaan dalam kegiatan diperoleh melalui dua sumber, yaitu dari suatu pemilik dan kreditur. Sumber pembelanjaan dari pemilik disebut juga sebagai ekuitas. Sedangkan sumber pembelanjaan yang diperoleh dari suatu kreditur bagi pemilik akan menjadi suatu kewajiban untuk mengembalikan, hal ini disebut juga sebagai kewajiban atau utang. Sehingga persamaannya dapat ditulis sebagai berikut ini:

\section{HARTA = UTANG + MODAL}

Dalam operasi uatu usaha dimungkinkan adanya pendapatan dan beban. Pendapatan adalah sebuah kenaikan harta yang diperoleh dari hasil penjualan barang atau jasa.

Sedangkan beban adalah sebuah penurunan harta, karena merupakan pengorbanan untuk dapat memperoleh pendapatan. Pendapatan yang mempunyai sifat menambah modal, sedangkan beban mempunyai sifat mengurangi modal. Dengan demikian pendapatan dan suatu beban akan mempengaruhi keadaan modal dalam perasamaan dasar akuntansi, dapat dicatat dalam komponen modal. Namun, untuk pada pengembangan akuntansi pencatatan pendapatan dan beban dapat dipisahkan dari modal. Sehingga bentuk persamaan dapat dinyatakan sebagai berikut ini :

\section{HARTA = UTANG + MODAL + PENDAPATAN + BEBAN}

\section{Metode Kooperatif Tipe TPS}

Model pembelajaran tipe think pair share merupakan model pembelajaran kooperatif sederhana yang berarti berfikir-berpasangan dan berbagi. Warsono (2012: 202) Model cooperative learning tipe think pair share yang berarti berfikirberpasangan-berbagi semula dikembangkan oleh Frank Lyman, juga oleh Spencer Kagan bersama Jack Hassard. Model ini oleh Johnson dan Johnson menyebutrnya tengoklah pasanganmu (Turn to Your Partner). Isjoni (2010: 78) menyatakan bahwa tehnik ini memberikan siswa kesempatan untuk bekerja sendiri serta bekerjasama dengan orang lain. Keunggulan teknik ini adalah optimalisasi partisipasi siswa, yaitu memberi kesempatan delapan kali lebih banyak kepada siswa untuk dikenali dan menunjukkan partisipasi mereka kepada orang lain.

Menurut Huda (2013: 206) menyatakan bahwa Strategi think pair share memperkenalkan gagasan tentang waktu "tunggu atau berfikir" (wait or think time) pada elemen pembelajaran kooperatif yang saat ini menjadi salah satu faktor ampuh dalam meningkatkan respons siswa terhadap pertanyaan. Sedangkan Menurut Arends (dalam Husaini. 2012. http://matheducations.blogsopt.com) menyatakan bahwa: Model pembelajaran think pair and share merupakan suatu cara yang efektif untuk membuat variasi suasana pola diskusi kelas. Dengan 
asumsi bahwa semua resitasi atau diskusi membutuhkan pengaturan untuk mengendalikan kelas secara keseluruhan, dan prosedur yang digunakan dalam think pair and share dapat memberi murid lebih banyak waktu berfikir, untuk merespon dan saling membantu.

Berdasarkan pendapat para ahli di atas, peneliti menyimpulkan bahwa pembelajaran tipe think pair share adalah pembelajaran yang memberikan kesempatan kepada siswa untuk bekerja sendiri, berpikir sendiri mengenai masalah-masalah yang diberikan oleh guru dan memberikan kesempatan kepada siswa untuk bekerjasama dengan teman, memberikan umpan balik untuk merespon dan saling membantu. Dalam tipe ini siswa dapat mengembangkan kemampuan dalam bekerjasama dan komunikasi antar siswa. Interaksi yang berlangsung selama proses pembelajaran dapat meningkatkan daya pikir dan meningkatkan aktivitas siswa dalam belajar.

\section{Langkah-Langkah Pembelajaran Tipe Think pair share}

Sama halnya dengan model-model pembelajaran lainnya, Model cooperative learning tipe think pair share memiliki langkah-langkah dalam pelaksanaannya. Menurut Warsono (2012: 203) Sintaks atau cara kerja pembelajaran tipe adalah sebagai berikut: a) Siswa duduk berpasangan, b) Guru melakukan presentasi dan kemudian mengajukan pertanyaan, c) Mula-mula siswa diberi kesempatan berfikir secara mandiri, d) Siswa kemudian saling berbagi (share) bertukar pikiran dengan pasanganya untuk menjawab pertanyaan guru, e) Guru memandu pleno kecil diskusi, setiap kelompok mengemukakan hasil diskusinya, f) Guru memberikan penguatan tentang prinsip-prinsip apa yang harus dibahas, menambahkan pengetahuan atau konsep yang luput dari perhatian siswa saat berdiskusi dengan pasanganya g) Simpulan dan refleksi. Sedangkan menurut Anita Lie (dalam Ningsih. 2011. eprint.uny.ac.id) menguraikan langkah-langkah pembelajaran tipe Think pair share adalah sebagai berikut: a) Guru membagi siswa dalam kelompok berempat dan memberikan tugas kepada semua kelompok; b) Setiap siswa memikirkan dan mengerjakan tugas tersebut sendiri; c) Siswa berpasangan dengan salah satu rekan dalam kelompok dan berdiskusi dengan pasangannya; d) Kedua pasangan bertemu kembali dalam kelompok berempat. Siswa mempunyai kesempatan untuk membagikan hasil kerjanya kepada kelompok berempat. Menurut Huda (2013: 207), langkah-langkah model cooperative learning tipe think pair share dalam pelaksanaan pembelajaran adalah sebagai berikut: a) Siswa ditempatkan dalam kelompok-kelompok. Setiap kelompok terdiri dari empat anggota/siswa; b) Guru memberikan tugas pada setiap kelompok; c) Masing-masing anggota memikirkan dan mengerjakan tugas tersebut sendiri-sendiri terlebih dahulu; d) Kelompok membentuk anggota-anggotanya secara berpasangan. Setiap pasangan mendiskusikan hasil pengerjaan individunya; e) Kedua pasangan lalu bertemu kembali dalam kelompoknya masing-masing untuk menshare hasil diskusinya.

Sesuai dengan salah satu ciri dari tipe think pair share yaitu pair (berpasangan), pada dasarnya tipe ini hanya dapat diterapkan pada kelas yang jumlah siswanya genap. Namun, tidak menutup kemungkinan tipe ini juga dapat diterapkan pada kelas yang jumlah siswanya ganjil. Hal ini diperkuat dengan 
pendapat Kristin (dalam Marbun 2013: 22) menyatakan apabila jumlah siswa pada suatu kelas ganjil, maka guru menggabungkan siswa tersebut dalam kelompok yang dirasa guru memiliki prestasi belajar rendah, karena akan banyak masukanmasukan atau pendapat dalam menyelesaikan soal-soal.

Berdasarkan pendapat para ahli di atas, maka dalam pelaksanaan kegiatan pembelajaran dengan jumlah kelompok siswa yang ganjil akan digabungkan dengan sebagian kecil siswa yang memiliki prestasi belajar rendah dan pada penelitian ini akan menggunakan langkah- langkah/Sintaks think pair share dari teori yang dikemukakan oleh Anita lie dan Huda dalam pembelajaran Akuntansi.

\section{Kelebihan dan Kekurangan Tipe Think pair share}

Di dalam model cooperative learning tipe think pair share memiliki kelebihan sekaligus kekurangan yang harus diperhatikan. Menurut Anita Lie (dalam Ningsih. 2011. eprint.uny.ac.id) memaparkan beberapa kelebihan dari pembelajaran tipe think pair share yaitu: (a) meningkatkan partisipasi siswa, (b) cocok untuk tugas sederhana, (c) lebih banyak kesempatan untuk kontribusi masing-masing anggota kelompok, (d) Interaksi lebih mudah, dan (e) lebih mudah dan cepat membentuknya. Selanjutnya menurut Lie (2004: 57), kelebihan tipe think pair share adalah sebagai berikut. 1) Memungkinkan siswa untuk merumuskan dan mengajukan pertanyaan-pertanyaan mengenai materi yang diajarkan karena secara tidak langsung memperoleh contoh pertanyaan yang diajukan oleh guru, serta memperoleh kesempatan untuk memikirkan materi yang diajarkan. 2) Siswa akan terlatih menerapkan konsep karena bertukar pendapat dan pemikiran dengan temannya untuk mendapatkan kesepakatan dalam memecahkan masalah. 3) Siswa lebih aktif dalam pembelajaran karena menyelesaikan tugasnya dalam kelompok, dimana tiap kelompok hanya terdiri dari 2 orang. 4) Siswa memperoleh kesempatan untuk mempersentasikan hasil diskusinya dengan seluruh siswa sehingga ide yang ada menyebar. 5) Memungkinkan guru untuk lebih banyak memantau siswa dalam proses pembelajaran. Sedangkan menurut Huda (2013: 206) menyatakan kelebihan/manfaat tipe think pair share antara lain a) memungkinkan siswa untuk bekerja sendiri dan bekerja sama dengan orang lain, b) mengoptimalkan partisipasi siswa dan c) memberikan kesempatan kepada siswa untuk menunjukkan partisipasi mereka kepada orang lain. Menurut Fadholi (dalam Husaini. 2012. http//matheducations.blogspot.com) mengemukakan 5 Kelebihan pembelajaran tipe think pair and share sebagai berikut: a) Memberi murid waktu lebih banyak untuk berfikir, menjawab, dan saling membantu satu sama lain; b) Lebih mudah dan cepat membentuk kelompoknya; c) Murid lebih aktif dalam pembelajaran karena menyelesaikan tugasnya dalam kelompok, dimana tiap kelompok hanya terdiri dari 2 orang; d) Murid memperoleh kesempatan untuk mempersentasikan hasil diskusinya dengan seluruh murid sehingga ide yang ada menyebar; e) Memungkinkan murid untuk merumuskan dan mengajukan pertanyaan-pertanyaan mengenai materi yang diajarkan karena secara tidak langsung memperoleh contoh pertanyaan yang diajukan oleh guru, serta memperoleh kesempatan untuk memikirkan materi yang diajarkan. Sedangkan kekurangan dalam pelaksanan tipe think pair share menurut Anita Lie (dalam Ningsih. 2011. eprint.uny.ac.id) menyatakan bahwa kekurangan tipe ini antara lain 
adalah : (a) banyak kelompok yang melaporkan dan perlu dimonitor, (b) lebih sedikit ide yang muncul, dan (c) jika ada perselisihan, tidak ada penengah. Selanjutnya menurut Fadholi (dalam Husaini. 2012. http//matheducations.blogspot.com) mengemukakan 5 Kelemahan tipe think pair and share sebagai berikut: a) Jumlah murid yang ganjil berdampak pada saat pembentukan kelompok, karena ada satu murid tidak mempunyai pasangan; b) Jika ada perselisihan,tidak ada penengah; c) Jumlah kelompok yang terbentuk banyak; d) Menggantungkan pada pasangan; e) Sangat sulit diterapkan di sekolah yang rata-rata kemampuan muridnya rendah.

Berdasarkan pendapat para ahli di atas, maka peneliti harus lebih optimal dalam melaksanakan kegiatan pembelajaran menggunakan tipe think pair share sehingga meminimalisir terjadinya kekurangankekurangan yang terjadi pada proses pembelajaran. Dalam hal ini peneliti menyimpulkan bahwa yang dimaksud dengan tipe think pair share dalam penelitian ini adalah pembelajaran yang memberikan kesempatan kepada siswa untuk bekerja sendiri dan bekerjasama dengan teman, dengan langkah-langkah sebagai berikut: 1) guru membagi siswa dalam kelompok yang terdiri dari 4-5 orang, 2) guru memberikan tugas kepada setiap kelompok, 3) setiap siswa memikirkan dan mengerjakan tugas secara individual, 4) kelompok membentuk anggota-anggotanya secara berpasangan, setiap pasangan mendiskusikan hasil pengerjaan individunya, dan 5) kedua pasangan lalu bertemu kembali dalam kelompoknya masing-masing untuk membagikan (share) hasil diskusinya.

\section{METODE PENELITIAN \\ Jenis Penelitian}

Jenis penelitian yang akan dilaksanakan adalah Penelitian Tindakan Kelas, Sebuah penelitian tindakan dalam menyelesaikan masalah pembelajaran di kelas dengan menerapkan teori pembelajaran yang relevan dengan materi pembelajaran, serta kesulitan pembelajaran yang ditemukan. Langkah-langkah penelitian terdiri dari perencanaan, tindakan, pengamatan, dan refleksi. Kegiatan penelitian tindakan secara keseluruhan menerapkan siklus kegiatan, tergantung dari sejauhmana pencapaian indicator keberhasilan.

\section{Tempat, Subjek dan Waktu Penelitian}

Penelitian ini dilaksanakan di SMAN I Lobalain. Adapun subjek penelitian yaitu kelas XII IPS yang berjumlah 36 orang. Penelitian ini dilaksanakan pada semester ganjil tahun ajaran 2019 / 2020 yaitu pada bulan Agustus sampai Oktober 2019

\section{Teknik Pengumpulan Data}

Pada penelitian ini peneliti mengambil dua jenis data yaitu data kuantitatif dan data kualitatif.

1. Data kuantitatif berupa:

Data hasil tes (postes) setiap siklus.

2. Data kualitatif berupa:

a. Data hasil observasi setiap siklus. 
b. Catatan lapangan.

c. Dokumentasi berupa foto.

\section{Instrumen - Instrumen Pengumpul Data yang Digunakan}

Instrumen pengumpul data yang digunakan dalam penelitian ini meliputi tes, observasi, angket (kuesioner), diskusi, catatan lapangan, dan dokumentasi.

1. Tes

Tes yang diberikan sesuai dengan materi dan siswa yang dipelajari.

2. Observasi

Observasi digunakan untuk menilai kegiatan yang berlangsung selama proses pembelajaran. Observasi ini menggunakan lembar observasi sistematis dimana pengamat menggunakan pedoman observasi sebagai instrumen pengamatan. Penilaian dilakukan dengan menggunakan skor 1 - 4. Dengan kriteria sebagai berikut: kurang (1), cukup (2), baik (3), sangat baik (4).

3. Catatan Lapangan

Catatan lapangan digunakan untuk mengetahui peristiwa atau kejadian penting yang terjadi saat proses pembelajaran berlangsung.

4. Dokumentasi

Dokumentasi digunakan untuk memperkuat data-data yang telah ada.

Dokumentasi yang akan peneliti gunakan adalah dokumentasi foto aktivitas siswa dan guru selama proses pembelajaran.

\section{HASIL PENELITIAN DAN PEMBAHASAN \\ Siklus I}

Aktivitas siswa selama kegiatan belajar mengajar siklus 1 dilihat dari aspek minat, perhatian, partisipasi dan presentasi selama proses pembelajaran dapat dilihat pada tabel 1 . berikut ini :

Tabel 1. Aktivitas Siswa Pada Siklus 1

\begin{tabular}{|c|c|c|c|c|}
\hline No & Kriteria & F & \% & Jumlah \% \\
\hline 1 & Sangat Baik & 5 & 13,88 & \multirow{2}{*}{55,55} \\
\hline 2 & Baik & 5 & 13,88 & \\
\hline 3 & Cukup & 10 & 27,77 & \\
\hline 4 & Kurang & 16 & 44,44 & 44,44 \\
\hline \multicolumn{2}{|c|}{ Jumlah } & 36 & 100 & 100 \\
\hline
\end{tabular}

Sumber : Hasil Penelitian, diolah (2019)

Keterangan : $1=$ tidak baik $2=$ cukup 3 =baik, dan $4=$ amat baik

Dari tabel di atas dapat dilihat bahwa dari jumlah siswa mendapat skor aktivitas belajar pada kategori kurang sebanyak 16 orang yang belum tuntas atau $44,44 \%$. Dengan demikian dapat dikatakan aktivitas siswa dalam pembelajaran sudah baik tetapi belum maksimal.

\section{Analisis Hasil Penelitian pada Siklus 1}

Berdasarkan hasil penelitian siklus I masih terdapat permasalahan dalam pembelajaran dengan model pembelajaran Think pair share yaitu sebagai berikut:

a. Persentase siswa yang telah mencapai KKM untuk aspek pemahaman konsep adalah 55,55\%, masih perlu ditingkatkan lagi. Hal ini disebabkan masih cukup 
banyak siswa yang tidak berpartisipasi dalam kegiatan pembelajaran di kelas sebanyak 16 orang. Guru masih kurang memperhatikan siswa yang pasif dalam pembelajaran.

b. Pada tahap penyajian materi, respon siswa masih kurang antusias. Hanya beberapa orang siswa yang menjawab pertanyaan guru dan masih ada yang belum memperhatikan penjelasan guru.

c. Kerjasama siswa dengan siswa lain pada siklus 1 masih kurang (siswa yang pandai belum dapat membantu yang lain dan partisipasi masih kurang)

d. Relevansi ketercapaian materi dan alokasi waktu yang tersedia belum sesuai, untuk siklus selanjutnya diperhatikan lagi

Hasil nilai siswa pada siklus I dapat dilihat pada tabel 2 di bawah ini :

Tabel 2. Hasil Nilai Siklus I

\begin{tabular}{|c|c|c|}
\hline No & Kategori & Jumlah \\
\hline 1 & Tuntas & 20 \\
\hline 2 & Belum Tuntas & 16 \\
\hline 3 & Total Nilai & 2427 \\
\hline 4 & Rata-Rata & 67,41 \\
\hline 5 & Prosentase Ketuntasan & $55,55 \%$ \\
\hline
\end{tabular}

Sumber : Hasil Penelitian, diolah (2019)

\section{Reflesi Hasil Tindakan}

Dalam pelaksanaan tindakan siklus I masih ada kelemahan yang harus diperbaiki sehingga pada penelitian sikus II dapat meningkat dengan baik. Kelemahan yang terjadi pada siklus I adalah :

a. Pada tahap penyajian materi, guru harus berusaha menarik perhatian siswa sehingga siswa antusias merespon dengan menyajikan permasalahan yang menarik untuk menggali pengetahuan awal siswa.

b. Menekankan kepada siswa bentuk evaluasi untuk meningkatkan kerjasama.

c. Setiap siswa diminta menanggapi laporan hasil kegiatan.

d. Manajemen waktu dalam kegiatan pembelajaran harus diperhatikan lagi

e. Memberikan pengarahan dan motivasi kepada siswa yang masih kurang dalam skor aktifitas belajar untuk lebih meningkatkan lagi.

Dengan melihat kelemahan yang dialami pada siklus I maka pada siklus II guru harus merencanakan persiapan yang lebih matang lagi sehingga prestasi yang dicapai siswa dapat meningkatkan lagi. Keuntungan yang diperoleh pada siklus I adalah ada 5 orang siswa yang tuntas mendapat kategori A yaitu nilai 90-95, mendapat kategori B sebanyak 5 orang dengan nilai 80 dan ketegori cukup sebanyak 10 orang. Siswa yang belum tuntas masih banyak sekitar 16 orang dan perlu ditingkatkan lagi pada siklus II.

\section{Siklus II}

Berdasarkan pelaksanaan tindakan dan observasi pada siklus II, diperoleh hasil penelitian seperti pada tabel berikut ini : 
Tabel 3. Aktivitas Siswa pada Siklus II

\begin{tabular}{|c|c|c|c|c|}
\hline No & Kriteria & F & \% & Jumlah \% \\
\hline 1 & Sangat Baik & 5 & 13,88 & \multirow{2}{*}{55,55} \\
\hline 2 & Baik & 15 & 41,66 & \\
\hline 3 & Cukup & 16 & 44,44 & \multirow{2}{*}{44,44} \\
\cline { 1 - 4 } 4 & Kurang & - & - & \\
\cline { 1 - 3 } & Jumlah & 36 & 100 & 100 \\
\hline
\end{tabular}

Sumber : Hasil Penelitian, diolah (2019)

Keterangan : $1=$ tidak baik $2=$ cukup $3=$ baik dan $4=$ amat baik

Pada tabel diatas menunjukan bahwa aktifitas siswa yang mengalami peningkatan yang baik ada 20 orang dengan prosentase 55,55 \% dan aktifitas yang mengalami peningkatan yang cukup baik ada 16 orang dengan prosentase $44,44 \%$. Dengan demikian hasil yang dicapai dalam aktifitas belajarnya meningkat mencapai $100 \%$.

Berdasarkan hasil penelitian siklus II diperoleh analisis sebagai berikut :

a. Persentase siswa yang telah mencapai KKM untuk aspek pemahanam konsep mengalami peningkatan dari siklus sebelumnya yaitu menjadi 100\%. Peningkatan yang sangat baik dimana semua siswa mencapai nilai KKM.

b. Pada tahap penyajian materi, respon siswa sudah baik.

c. Keaktifan siswa dalam kerjasama telah mengalami peningkatan.

d. Partisipasi siswa dalam diskusi laporan hasil kegiatan mengalami peningkatan.

e. Relevansi ketercapaian materi dan alokasi waktu sudah sesuai.

Tabel 4. Hasil Nilai Siswa pada Siklus II

\begin{tabular}{|c|c|c|}
\hline No & Kategori & Jumlah \\
\hline 1 & Tuntas & 36 \\
\hline 2 & Belum Tuntas & - \\
\hline 3 & Total Nilai & 3060 \\
\hline 4 & Rata-Rata & 85 \\
\hline 5 & Prosentase Ketuntasan & $100 \%$ \\
\hline
\end{tabular}

Sumber : Hasil Penelitian, diolah (2019)

Pada tabel di atas siswa dibagi dalam bentuk kelompok dengan tujuan agar bisa bekerjasama memecahkan masalah yaitu tugas yang diberikan. Dengan demikian hasil yang dicapai semua siswa meningat dan tuntas pada siklus II.

\section{Refleksi Tindakan}

Tindakan perencanaan sampai dengan hasil nilai siklus II pada pelaksanaan siklus II mengalami peningkatan yang signifikan dengan keuntungan yang dicapai adalah :

a. Aktivitas siswa dalam mengukuti pelajaran baik.

b. Manajemen waktu dalam kegiatan pembelajaran tetap diperhatikan.

c. Kerjasama diantara siswa dalam mengerjakan soal dengan baik.

d. Hasil nilai yang dicapai pada siklus II adalah tuntas $100 \%$ dengan nilai tertinggi 90 sebanyak 12 orang, 85 sebanyak 12 orang dan 80 sebanyak 12 orang.

e. Pelaksanaan siklus II dinyatakan berhasil dan tidak dilanjutkan lagi ke siklus III. 


\section{Pembahasan}

Dari hasil penelitian diperoleh bahwa terdapat peningkatan rata-rata skor test siswa pada siklus I tidak mencapai KKM sebanyak 16 orang, setelah ditingkatkan lagi model pembelajaran Think Pair Share pada siklus II berupa skor test telah mencapai KKM. Keterlibatan siswa secara langsung dalam kegiatan diskusi memotivasi siswa untuk membangun konsep sendiri dalam memecahkan masalah secara kritis sehingga proses belajar yang dialami siswa akan lebih bermakna. Kerjasama dan tanggung jawab setiap siswa atas keberhasilannya dapat mempelajari materi dengan tuntas. Dengan demikian dapat dikatakan bahwa model pembelajaran Think pair share dapat meningkatkan hasil belajar siswa kelas XII IPS dalam mempelajari persamaan dasar akuntansi.

Untuk melihat hasil perbandingan siklus I dan siklus II kita dapat melihat hasil tabel dibawah ini :

Tabel 5. Perbandingan Nilai siklus I dan Siklus I

\begin{tabular}{|c|c|c|c|}
\hline No & Uraian & Siklus I & Siklus II \\
\hline 1 & Aktivitas siswa & $55,55 \%$ & $100 \%$ \\
\hline 2 & Nilai rata-rata & 65,28 & 85 \\
\hline 3 & Ketuntasan & $55,55 \%$ & $100 \%$ \\
\hline 4 & Siswa yang tuntas & 15 & 36 \\
\hline 5 & Siswa yg tidak tuntas & 16 & - \\
\hline
\end{tabular}

Sumber : Hasil Penelitian, diolah (2019)

\section{KESIMPULAN DAN SARAN \\ Kesimpulan}

Berdasarkan temuan penelitian dan pembahasaan, maka diperoleh kesimpulan :

a. Penerapan model Think pair share agar dapat meningkatkan hasil belajar dan prestasi belajar siswa kelas XII IPS pada pelajaran Ekonomi / Akuntansi materi persamaan dasar akuntansi secara keseluruhan telah berlangsung secara optimal. Guru tidak lagi menggunakan sistem teacher centered, tetapi guru telah mengaktifkan siswa dalam diskusi bersama untuk memecahkan masalah atau soal yang diberikan. Dan guru berperan sebagai fasilitator dan motivator dalam pembelajaran.

b. Penerapan pembelajaran Think pair share dapat meningkatkan hasil belajar siswa Kelas XII IPS di SMAN I Lobalain. Hal ini dapat dilihat dari adanya peningkatan hasil belajar yang diperoleh siswa setelah diterapkan model pembelajaran Think pair share. Peningkatan hasil belajar ini sejalan dengan peningkatan aktivitas siswa dalam pembelajaran dan sikap positif siswa terhadap pembelajaran berdasarkan model pembelajaran Think pair share.

\section{Saran}

Dengan merujuk pada temuan penelitian dan pembahasan, peneliti mengemukakan saran sebagai berikut :

a. Model pembelajaran Think pair share dapat diterapkan pada materi lainnya dalam upaya meningkatkan hasil belajar siswa.

b. Diperlukan pengefektifan waktu selama kegiatan pembelajaran berlangsung 


\section{DAFTAR PUSTAKA}

A, Supratiknya. 2012. Penilaian Hasil Belajar dengan Teknik Nontes. Yogyakarta: Universitas Sanata Dharma

Agung, Iskandar. 2012. Panduan Penelitian Tindakan Kelas Bagi Guru. Jakarta: Bestari Buana Murni.

Ahmad, Susanto. 2013. Teori Belajar dan Pembelajaran di Sekolah Dasar. Jakarta: Kencana Prenada Media Group.

Andrianto, Dedy. 2011. Lingkungan Sekitar sebagai Sumber Belajar Anak. Direktorat Pendidikan Anak Usia Dini Kementerian Pendidikan Nasional (diunduh pada tanggal 20 April 2014).

Anita Lie. 2010. Cooperatif Learning Mempraktikan Cooperatif Learning diruang-ruang kelas. Jakarta: Grasindo.

Huda, Miftahul. 2011. Cooperative Learning Metode, Teknik, Struktur dan Model Penerapan. Yogyakarta: Pustaka Pelajar.

Isjoni. 2010. Cooperative Learning. Alfabeta. Bandung.

Marbun, Rosnita. 2013. Penerapan Model Cooperative Learning Tipe Think pair share Untuk Meningkatkan Aktivitas dan Hasil Belajar Siswa Pada Pembelajaran Matematika Kelas IVA SD Negeri 1 Panjang Selatan Bandar Lampung Tahun Pelajaran 2012/2013. Universitas Lampung. Bandar Lampung.

Ningsih, Ari Yunita. 2011. Penggunaan Media Kelereng dalam Model Pembelajaran Kooperatif (Think Pair Shre) untuk Meningkatkan Kemampuan Berhitung Perkalian Siswa Kelas II SD Negeri 01 Dagen Jaten Karanganyar Tahun Pelajaran 2010/2011. Eprint. Uny. ac.id. (diakses pada 29 Maret 2015).

Sudjana, Nana. 2011. Penilaian Hasil Proses Belajar Mengajar. Bandung: PT Remaja Rosdakarya.

Warsono \& Hariyanto. 2012. Pembelajaran Aktif. Bandung: PT Remaja Rosdakarya. 